\title{
ДИСКРИМІНАНТНИЙ АНАЛІЗ В ОЦІНЦІ ФУНКЦІОНАЛЬНОЇ I РУХОВОЇ ПІДГОТОВЛЕНОСТІ ДІВЧАТ СТАРШИХ КЛАСІВ
}

\author{
Худолій О.М., Іващенко О.В. \\ Харківський національний педагогічний університет імені Г. С. Сковороди
}

DOI: 10.17309/tmfv.2014.4.1113

\begin{abstract}
Анотація. Мета дослідження - визначити методологічні підходи до педагогічного контролю рухової та функціональної підготовленості дівчат старших класів.

Методи дослідження. Для вирішення поставлених завдань були застосовані такі методи дослідження: аналіз наукової літератури, педагогічне тестування та методи математичної статистики.

Для оцінки функціональної і рухової підготовленості дівчат 9-11 класів реєструвалися результати проб Штанге, Генчі, Серкіна та рухових тестів. У дослідженні прийняли участь дівчата 9 класу -24 чоловік, 10 класу - 21 чоловік, 11 класу - 26 чоловік.

Результати. Нормовані коефіцієнти канонічної дискримінантної функції дозволяють визначити співвідношення вкладу змінних у результат функції. 3 найбільшим вкладом в канонічну функцію 1 входять змінні 3, 4 і 7: чим більші значення цих змінних, тим більше значення функції. 3 найбільшим вкладом в канонічну функцію 2 входять змінні 1, 8 і 5: чим більші значення цих змінних, тим більше значення функції. Перша функція на 96,9\% пояснює варіацію результатів, друга - на 3,1\%. Вищевикладене свідчить про можливість класифікації вікових відміностей дівчат 9-11 класів на основі тестування функціональної, силової і координаційної підготовленості. Структурні коефіцієнти канонічної дискримінантної функції свідчать, що вона найбільш суттєво зв’язана 3 № 9, 7 і 6 змінними: отже суттєва різниця між дівчатами 9-11 класів спостерігається у пробах Серкіна, Штанге, швидкісній силі.

Висновки. Для підсумкового педагогічного контролю рухової і функціональної підготовленості дівчат 9-11 класів може бути використана перша дискримінантна функція з акцентом на найбільш інформативні змінні. Ключові слова. Дискримінантна функція; педагогічний контроль; класифікація; моделювання; рухова підготовленість; дівчата 9-11 класів.
\end{abstract}

Постановка проблеми. Здоров'я людини формується в дитячому і підлітковому віці. За науковими даними стан здоров'я школярів за останні роки значно погіршився (Бальсевич В.К., 2000; Ильин П.Е., 2003; Круцевич Т.Ю., Безверхня Г.В., 2010; Носко М.О., Єрмаков С.С., Гаркуша С.В., 2010). У Цільовій комплексній програмі «Фізичне виховання - здоров'я нації» зазначається, що в Україні склалася вкрай незадовільна ситуація із станом здоров'я населення, а особливо дітей і підлітків. Майже 90 \% учнів мають відхилення у стані здоров'я, понад 50 \% - незадовільну фізичну підготовленість.

Однією з умов підвищення рівня рухової підготовленості школярів $є$ організація педагогічного контролю як на уроках фізичної культури (Худолій О.М., 2008; Шиян Б. М., Папуша В. Г., 2005; Круцевич Т.Ю., Безверхня Г.В., 2010), так і в умовах спортивного тренування (Худолій О. М., Єрмаков С. С., 2011; Худолій О.М., Іващенко О.В., 2013, 2014). Процедурою педагогічного контролю $є$ класифікація поточного стану рухової і функціональної підготовленості від якої залежить прийняття рішення в процесі управління фізичним вихованням дітей $\mathrm{i}$ підлітків.

(c) Іващенко О.В., Худолій О.М., 2014
У дослідженнях Худолія О.М., Єрмакова С.С. (2011), Худолія О.М., Іващенко О.В. (2013, 2014) розглядаються моделі поцесу розвитку рухових здібностей, які можуть використовуватися для поточного і підсумкового контролю підготовленості дітей і підлітків. У виконаних дослідженнях за темою 13.04 «Моделювання процесу навчання та розвитку рухових здібностей у дітей і підлітків» (20132014 рр.) (номер державної реєстрації 0113 U002102) визначені особливості рухової підготовленості дівчат 7-8 класів (О. М. Худолій, О. В. Іващенко, 2014), 8-9 класів (О. В. Іващенко, Т. В. Карпунець, Ю.В. Крінін, 2014), встановлено, що канонічна дискримінантна функція може бути використана для оцінки і прогнозування динаміки функціональної і рухової підготовленості дівчат середніх класів. У роботах О. В. Іващенко, Г. П. Шепеленко (2014), О. В. Іващенко, С. А. Пашкевич, Ю. В. Крінін (2014), О. В. Іващенко, О. М. Худолій (2014), О. В. Іващенко (2014) визначені особливості динаміки рухової підготовленості у хлопців 8-9, 9-11 класів. Встановлено, що для визначення інформативних показників для кожного класу може бути використаний факторний аналіз, а для оцінки динаміки рухової підготовленості - дискримінантний.

Однак, у доступній науковій літературі недостатньо приділяється уваги дослідженню можли- 
вості використання дискримінантного аналізу як методу педагогічного контролю стану рухової та функціональної підготовленості дітей і підлітків. Тому вирішення питання оцінки та виявлення особливостей функціональної та рухової підготовленості школярів старших класів залишається актуальним.

Зв'язок роботи з науковими програмами, планами, темами. Дослідження виконано згідно плану науково-дослідної роботи Міністерства освіти і науки, молоді і спорту України з теми 13.04 «Моделювання процесу навчання та розвитку рухових здібностей у дітей і підлітків» (2013-2014 рр.) (номер державної реєстрації 0113U002102).

\section{Матеріал і методи.}

Мета роботи - визначити методологічні підходи до педагогічного контролю рухової та функціональної підготовленості дівчат старших класів.

Методи дослідження. Для вирішення поставлених завдань були застосовані такі методи дослідження: аналіз науково-методичної літератури, педагогічне тестування та методи математичної статистики.

У плануванні дослідження використані концептуальні підходи до розробки програми наукових досліджень у фізичному вихованні і спорті (Ашмарин Б.А., 1978; Круцевич Т.Ю., 1985; Філін В. П., Ровний А. С., 1992; Худолій О.М., Іващенко О.В., 2014).

У програму тестування ввійшли загальновідомі тести (Лях В.И., 2000; Сергієнко Л. П., 2001): стрибки з «надбавками» (кількість стрибків у заданому коридорі), човниковий біг $4 \times 9$ м (с), згинання і розгинання рук в упорі лежачи (рази), згинання і розгинання рук у висі (рази), вис на зігнутих руках (с), стрибок у довжину з місця (см).

Для оцінки функціонального стану були використані проби Штанге, Генчі і Серкіна (Дубров- ский В. И., 2005; Шиян Б. М., Папуша В. Г., 2005). У дослідженні прийняли участь дівчата 9 класу 24 чоловік, 10 класу - 21 чоловік, 11 класу - 26 чоловік.

Результати дослідження. Результати дослідження наведені в таблицях 1-3.

Аналіз показує, що в результатах тестування дівчат 9 і 10 класів спостерігаються статистично достовірні розбіжності у функціональній підготовленості дихальної і серцево-судинної системи, а також у координаційній і власне силовій підготовленості. За функціональною підготовленістю дівчата оцінюються як здорові нетреновані (див. табл. 1).

Аналіз свідчить, що за результатами тестування спостерігаються між дівчатами 9 і 11 класів за показниками тестів $1-3$ та 6-9 статистично достовірні розбіжності ( $<<0,05: 0,001)$. За функціональним станом функції дихання і кровообігу дівчата 11 класу оцінюються як здорові нетреновані (див. табл. 2).

Статистично достовірні розбіжності між дівчатами 10 і 11 класів спостерігаються у тестах, які характеризують функціональну, координаційну і власне силову підготовленість $(\mathrm{p}<0,001)$. Дівчата 10 класів мають кращу підготовленість за результатами батареї тестів $(\mathrm{p}<0,001)$, а також мають кращі показники статичної сили, координації рухів та функціонального стану дихальної та серцево-судинної системи (див. табл. 3).

У таблицях 4-7 наведені результати дискримінантного аналізу, що дозволяє класифікувати учнів 9-11 класів за функціональним станом і рівнем рухової підготовленості.

Перша канонічна функція пояснює варіацію результатів на 96,9 \%, друга - на 3,1 \%, що свідчить про їх високу інформативність (див. табл. 4). Коефіцієнт кореляції між розрахунковими значеннями

Таблиия 1

Результати аналізу рухової і функціональної підготовленості дівчат 9-10 класів

\begin{tabular}{|c|c|c|c|c|c|c|c|}
\hline \multirow{2}{*}{ № } & \multirow[b]{2}{*}{ Тест } & \multicolumn{2}{|c|}{9 клас $(\mathrm{n}=24)$} & \multicolumn{2}{|c|}{10 клас $(\mathrm{n}=21)$} & \multirow{2}{*}{$\mathrm{t}$} & \multirow{2}{*}{$\mathrm{P}$} \\
\hline & & $\mathrm{x}$ & $\mathrm{s}$ & $\mathrm{x}$ & $\mathrm{s}$ & & \\
\hline 1 & Стрибки з «надбавками», рази & 1,78 & ,97 & 4,45 & ,82 & $-7,272$ & $<0,001$ \\
\hline 2 & Човниковий біг $4 \times 9$ м, с & 11,92 & ,23 & 9,94 &, 80 & 8,759 & $<0,001$ \\
\hline 3 & Згинання і розгинання рук в упорі лежачи, рази & 19,57 & 5,08 & 21,91 & 10,06 &,- 758 & $>0,05$ \\
\hline 4 & Згинання і розгинання рук у висі, рази & 4,43 & 1,82 & 8,55 & 5,57 & $-2,604$ & $<0,016$ \\
\hline 5 & Вис на зігнутих руках, с & 30,59 & 13,50 & 38,09 & 11,51 & $-1,468$ & $>0,05$ \\
\hline 6 & Стрибок у довжину з місця, см & 191,07 & 14,16 & 182,18 & 22,08 & 1,223 & $>0,05$ \\
\hline 7 & Проба Штанге, с & 61,71 & 10,69 & 55,36 & 10,02 & 1,514 & $>0,05$ \\
\hline 8 & Проба Генчі, с & 39,39 & 11,39 & 38,45 & 9,70 & ,217 & $>0,05$ \\
\hline 9 & Проба Серкіна, с & 21,72 & 5,14 & 40,28 & 6,64 & $-7,885$ & $<0,001$ \\
\hline
\end{tabular}


ISSN 1993-7989 (print). ISSN 1993-7997 (online). Теорія та методика фізичного виховання. 2014. № 04

Результати аналізу рухової і функціональної підготовленості дівчат 9-11 класів

\begin{tabular}{|c|c|c|c|c|c|c|c|}
\hline \multirow{2}{*}{ № } & \multirow[b]{2}{*}{ Тест } & \multicolumn{2}{|c|}{9 клас $(\mathrm{n}=24)$} & \multicolumn{2}{|c|}{11 клас (n=26) } & \multirow{2}{*}{$\mathrm{t}$} & \multirow{2}{*}{$\mathrm{P}$} \\
\hline & & $\mathrm{x}$ & s & $\mathrm{x}$ & s & & \\
\hline 1 & Стрибки з «надбавками», рази & 1,78 & ,97 & 3,68 & 1,01 & $-5,216$ & $<0,001$ \\
\hline 2 & Човниковий біг $4 \times 9$ м, с & 11,92 & ,23 & 10,21 & 1,03 & 6,065 & $<0,001$ \\
\hline 3 & Згинання і розгинання рук в упорі лежачи, рази & 19,57 & 5,08 & 14,81 & 7,38 & 2,026 & $<0,052$ \\
\hline 4 & Згинання і розгинання рук у висі, рази & 4,43 & 1,82 & 5,68 & 3,13 & $-1,318$ & $>0,05$ \\
\hline 5 & Вис на зігнутих руках, с & 30,59 & 13,50 & 28,12 & 11,49 &, 541 & $>0,05$ \\
\hline 6 & Стрибок у довжину з місця, см & 191,07 & 14,16 & 171,75 & 15,32 & 3,568 & $<0,001$ \\
\hline 7 & Проба Штанге, с & 61,71 & 10,69 & 46,00 & 6,05 & 5,035 & $<0,001$ \\
\hline 8 & Проба Генчі, с & 39,39 & 11,39 & 28,37 & 6,57 & 3,295 & $<0,001$ \\
\hline 9 & Проба Серкіна, с & 21,72 & 5,14 & 32,55 & 4,15 & $-6,373$ & $<0,001$ \\
\hline
\end{tabular}

Результати аналізу рухової і функціональної підготовленості дівчат 10-11 класів

\begin{tabular}{|c|c|c|c|c|c|c|c|}
\hline \multirow{2}{*}{ № } & \multirow[b]{2}{*}{ Тест } & \multicolumn{2}{|c|}{10 клас (n=21) } & \multicolumn{2}{|c|}{11 клас (n=26) } & \multirow{2}{*}{$\mathrm{t}$} & \multirow{2}{*}{$\mathrm{P}$} \\
\hline & & $\mathrm{x}$ & s & $\mathrm{x}$ & s & & \\
\hline 1 & Стрибки з «надбавками», рази & 4,45 &, 82 & 3,68 & 1,01 & 2,080 & $<0,048$ \\
\hline 2 & Човниковий біг $4 \times 9$ м, с & 9,94 &, 80 & 10,21 & 1,03 &,- 720 & $>0,05$ \\
\hline 3 & Згинання і розгинання рук в упорі лежачи, рази & 21,91 & 10,06 & 14,81 & 7,38 & 2,117 & $<0,044$ \\
\hline 4 & Згинання і розгинання рук у висі, рази & 8,55 & 5,57 & 5,68 & 3,13 & 1,704 & $>0,05$ \\
\hline 5 & Вис на зігнутих руках, с & 38,09 & 11,51 & 28,12 & 11,49 & 2,212 & $<0,036$ \\
\hline 6 & Стрибок у довжину з місця, см & 182,18 & 22,08 & 171,75 & 15,32 & 1,453 & $>0,05$ \\
\hline 7 & Проба Штанге, с & 55,36 & 10,02 & 46,00 & 6,05 & 3,032 & $<0,006$ \\
\hline 8 & Проба Генчі, с & 38,45 & 9,70 & 28,37 & 6,57 & 3,226 & $<0,003$ \\
\hline 9 & Проба Серкіна, с & 40,28 & 6,64 & 32,55 & 4,15 & 3,729 & $<0,001$ \\
\hline
\end{tabular}

дискримінантної функції і показниками належності до групи рівний $\mathrm{r}=0,978$ і свідчить про високу прогностичність першої канонічної функції. Власне значення першої канонічної функції свідчить про вдало підібрані коефіцієнти в ній.

У таблиці 5 наведений матеріал аналізу канонічних функцій. Перший рядок містить значення $\lambda=0,025$ та статистичну значущість $\mathrm{p}=0,001$ для всього набору канонічних функцій, другий рядок містить дані після виключення першої функції. Перша і друга функції мають високу дискримінантну здатність і значення в інтерпретації відносно генеральної сукупності.

У таблиці 6 наведені нормовані коефіцієнти канонічної дискримінантної функції, які дозволяють визначити співвідношення вкладу змінних у результат функції. 3 найбільшим вкладом в канонічну функцію 1 входять змінні 3, 4 і 7: чим більші значення цих змінних, тим більше значення функції. 3 найбільшим вкладом в канонічну функцію 2 входять змінні 1, 8 і 5: чим більші значення цих змінних, тим більше значення функції. Перша функція на 96,9\% пояснює варіацію результатів, друга - на 3,1\%. Вищевикладене свідчить про можливість класифікації вікових відміностей дівчат 9-11 класів на основі тестування функціональної, силової і координаційної підготовленості.

У таблиці 7 наведені координати центроїдів для трьох груп. Вони дозволяють інтерпретувати канонічну функцію відносно ролі в класифікації. На 
Таблиия 4

Канонічна дискримінантна функиія. Власні значення

\begin{tabular}{|l|r|l|l|c|}
\hline Функція & $\begin{array}{l}\text { Влас- } \\
\text { ні зна- } \\
\text { чення }\end{array}$ & $\begin{array}{l}\text { \% поясненої } \\
\text { дисперсії }\end{array}$ & $\begin{array}{l}\text { Кумулятив- } \\
\text { ний \% }\end{array}$ & $\begin{array}{l}\text { Канонічна } \\
\text { кореляція }\end{array}$ \\
\hline 1 & 22,454 & 96,9 & 96,9 &, 978 \\
\hline 2 &, 728 & 3,1 & 100,0 &, 649 \\
\hline
\end{tabular}

Канонічна дискримінантна функція. Лямбда Уілкса

\begin{tabular}{|l|c|c|c|c|}
\hline $\begin{array}{l}\text { Перевірка } \\
\text { функцій }\end{array}$ & $\begin{array}{l}\text { Л я м б д а } \\
\text { Уілкса }\end{array}$ & Х-квадрат & $\begin{array}{l}\text { с т у п е н i } \\
\text { свободи }\end{array}$ & $\mathrm{p}$ \\
\hline від 1 до 2 &, 025 & 125,864 & 18 &, 000 \\
\hline 2 &, 579 & 18,592 & 8 &, 017 \\
\hline
\end{tabular}

Таблиця 6

Нормовані коебіицєнти канонічної дискримінантної функиї

\begin{tabular}{|l|l|c|c|}
\hline \multirow{2}{*}{$\begin{array}{c}\text { № } \\
\text { теста }\end{array}$} & \multicolumn{1}{|c|}{ Назва теста } & \multicolumn{2}{c|}{ Функція } \\
\cline { 3 - 4 } & \multicolumn{1}{|c|}{1} & 2 \\
\hline 1 & Стрибки з «надбавками», рази &,- 099 &, 696 \\
\hline 2 & Човниковий біг 4×9 м, с &, 599 &, 326 \\
\hline 3 & $\begin{array}{l}\text { Згинання і розгинання рук в } \\
\text { упорі лежачи, рази }\end{array}$ & 1,290 &, 554 \\
\hline 4 & $\begin{array}{l}\text { Згинання і розгинання рук у } \\
\text { висі, рази }\end{array}$ & $-1,131$ &,- 375 \\
\hline 5 & Вис на зігнутих руках, с &,- 002 &, 656 \\
\hline 6 & Стрибок у довжину з місця, см &, 478 &,- 179 \\
\hline 7 & Проба Штанге, с &, 932 &, 217 \\
\hline 8 & Проба Генчі, с &, 924 &, 658 \\
\hline 9 & Проба Серкіна, с & $-1,713$ &, 012 \\
\hline
\end{tabular}

Функції в центроїдах груп

\begin{tabular}{|l|l|}
\hline \multirow{2}{*}{ Клас } & Функція \\
\cline { 2 - 2 } & 1 \\
\hline 9 клас & 6,334 \\
\hline 10 клас & $-3,414$ \\
\hline 11 клас & $-3,195$ \\
\hline
\end{tabular}

позитивному полюсі знаходиться центроїд для 9 класу, на відємному - центроїди для 10 та 11 класу. Що свідчить про суттєву різницю в підготовленості дівчат 9-11 класів.

У таблиці 8 наведені структурні коефіцієнти канонічної дискримінантної функції, які є коефіцієнтами кореляції змінних з функцією. Так, функція найбільш суттєво зв’язана з № 9, 7 і 6 змінними: отже суттєва різниця між дівчатами 9-11 класів
Табличя 8

Структурні коебіциєнти канонічної дискримінантної функиї

\begin{tabular}{|l|l|c|c|}
\hline \multirow{2}{*}{$\begin{array}{c}\text { No } \\
\text { теста }\end{array}$} & \multicolumn{1}{|c|}{ Назва теста } & \multicolumn{2}{|c|}{ Функція } \\
\cline { 3 - 4 } & & 1 & 2 \\
\hline 2 & Човниковий біг $4 \times 9$ м, с &, $243^{*}$ &,- 141 \\
\hline 9 & Проба Серкіна, с &,- 280 &, $686^{*}$ \\
\hline 8 & Проба Генчі, с &, 075 &, $535^{*}$ \\
\hline 7 & Проба Штанге, с &, 136 &, $523^{*}$ \\
\hline 3 & $\begin{array}{l}\text { Згинання і розгинання рук в } \\
\text { упорі лежачи, рази }\end{array}$ &, 024 &, $459^{*}$ \\
\hline 5 & Вис на зігнутих руках, с &,- 015 &, $394^{*}$ \\
\hline 4 & $\begin{array}{l}\text { Згинання і розгинання рук у } \\
\text { висі, рази }\end{array}$ &,- 071 &, $374^{*}$ \\
\hline 1 & $\begin{array}{l}\text { Стрибки з «надбавками», } \\
\text { рази }\end{array}$ &,- 243 &, $365^{*}$ \\
\hline 6 & $\begin{array}{l}\text { Стрибок у довжину з місця, } \\
\text { см }\end{array}$ &, 091 &, $307^{*}$ \\
\hline \hline
\end{tabular}

* максимальна за абсолютною величина кореляція між змінними і дискримінантними функціями

спостерігається у функціональній і руховій підготовленості: проба Серкіна, швидкісна сила, координація рухів і власне сила.

У таблиці 9 наведені результати класифікації груп, 80,5 \% вихідних згрупованих спостережень класифіковано вірно. Таким чином, канонічна дискримінантна функція може бути використана для класифікації вікових особливостей розвитку дівчат 9-11 класів. Графічний матеріал наведений на рис.1 свідчить про щільність об’єктів внутрі кожного класу і про виразну межу між класами. Це дає можливість стверджувати, що класифікація дівчат 9-11 класів можлива за наведеною батареєю тестів.

Обговорення результатів дослідження. Отримані результати доповнюють відомості про особливості розвитку рухових здібностей у дітей і підліт-

Таблиия 9

Результати класифікації груп

\begin{tabular}{|c|c|c|c|c|c|c|}
\hline & & \multirow[t]{2}{*}{$\begin{array}{l}\text { Класи - } \\
\text { фікатор }\end{array}$} & \multicolumn{3}{|c|}{$\begin{array}{l}\text { Прогнозована належ- } \\
\text { ність до групи }\end{array}$} & \multirow[t]{2}{*}{ Ітого } \\
\hline & & & 9 & 10 & 11 & \\
\hline \multirow{6}{*}{ 㿣 } & \multirow{3}{*}{ Частота } & 9 клас & 14 & 0 & 0 & 14 \\
\hline & & 10 клас & 0 & 6 & 5 & 11 \\
\hline & & 11 клас & 0 & 3 & 13 & 16 \\
\hline & \multirow{3}{*}{$\%$} & 9 клас & 100,0 & ,0 &, 0 & 100,0 \\
\hline & & 10 клас & , 0 & 54,5 & 45,5 & 100,0 \\
\hline & & 11 клас &, 0 & 18,8 & 81,3 & 100,0 \\
\hline
\end{tabular}




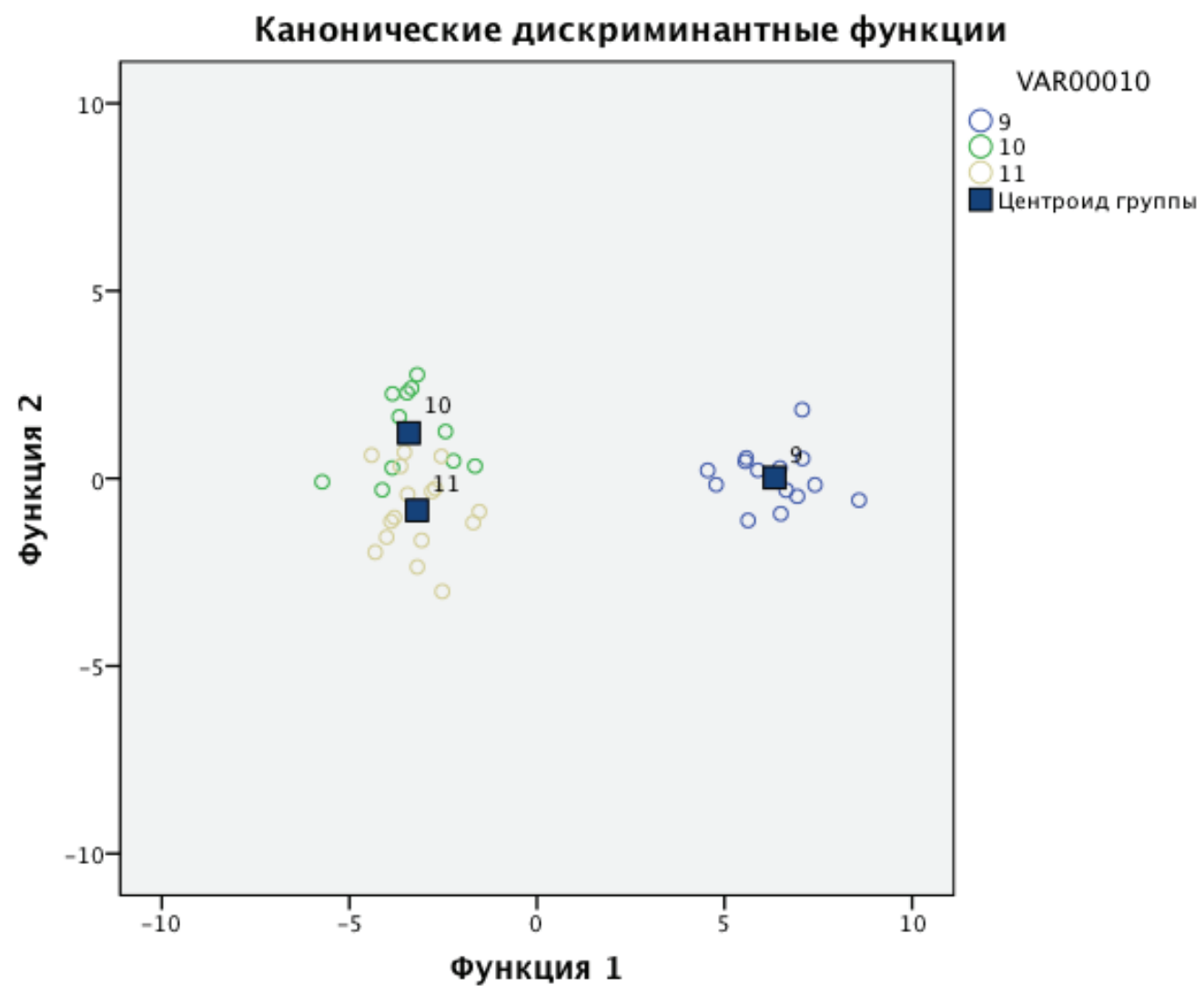

Рис. 1. Графічне відображення результатів класифікації

ків (Худолій О. М., Марченко С. І., 2007; Марченко С. І., 2008, 2009; Худолій О. М., Тітаренко А. А., 2010; Тітаренко А. А., Худолій О. М. 2011; Іващенко О.В., Пелепенко О.В., 2011; Худолій О. М., Іващенко О. В., Піменов О. О., 2012; Соляник I. Є., 2013), про можливість отримання нової інформації за допомогою методу моделювання (Іващенко О.В., 1988; Єрмаков, С. С., 2001, 2010; Худолій О. М., 2011; Худолій О. М., Іващенко О. В., 2013; Adashevskiy, V. M., Iermakov, S. S., 2013; Худолій O.M., Іващенко O.B., 2014).

У дослідженнях у фізичному вихованні і спорті дискримінантна функція використовується для класифікації учнів за спонуканнями до занять спортом (Milić, M., Milavić, B., \& Grgantov, Z. (2011), за pyховою активністю (Gert-Jan de Bruijn and Benjamin Gardner (2011), для класифікація груп на спортсмени і неспортсмени (Lulzim, I., (2013), для визначення динаміки фізичного стану дітей 9-12 років під впливом фітнес програм (Dorita Du Toit, Anita E. Pienaar \& Leani Truter (2011), для підсумкового контролю функціональної і рухової підготовленості дітей і підлітків (Худолій О. М., Іващенко О. В., 2013, 2014).
Geoffrey D. Broadhead And Gabie E. Church (1982) вказують на можливість використання дискримінантного аналізу для класифікації моторної активності дітей 5-12 років в залежності від ії обсягу, рівняння дискримінантної функції дозволяють 93\% згрупованих даних класифікувати вірно.

Результати дослідження вказують на необхідність структурного і функціонального аналізу рухової підготовленості дітей і підлітків і опираються на дослідження Арефьева В.Г. (2014), Худолія О. М., Іващенко О. В. (2014), Ж. Л. Козіної, Н. Поповой (2013), Т. М. Кравчук, О. С. Курочки (2013), Ткаченко С.Н. (2014).

Проведений аналіз підтверджує, що відділити дівчат 9 класу від дівчат 10 і 11 класів можна за вказаним набором показників з акцентом на функціональні проби і результати швидкісно-силової підготовленості.

Отже, дискримінантний аналіз дозволив дати відповідь на питання наскільки достовірно можно відділити один клас від іншого за набором запропонованих змінних; які з цих змінних найбільш суттєво впливають на розрізнення класів; до якого класу належить об'єкт на основі значень дискримінантних змінних. 


\section{Висновки}

1. Аналіз показує, що в результатах тестування дівчат 9 і 10 класів спостерігаються статистично достовірні розбіжності у функціональній підготовленості дихальної і серцево-судинної системи, а також у координаційній і власне силовій підготовленості. За функціональною підготовленістю дівчата оцінюються як здорові нетреновані.

2. Аналіз свідчить, що за результатами тестування спостерігаються між дівчатами 9 і 11 класів за показниками тестів $1-3$ та 6-9 статистично достовірні розбіжності ( $<<0,05: 0,001)$. За функціональним станом функції дихання і кровообігу дівчата 11 класу оцінюються як здорові нетреновані.

3. Статистично достовірні розбіжності між дівчатами 10 i 11 класів спостерігаються у тестах, які характеризують функціональну, координаційну і власне силову підготовленість ( $<<0,001)$. Дівчата 10 класів мають кращу підготовленість за результатами батареї тестів ( $<00,001)$, а також мають кращі показники статичної сили, координації рухів та функціонального стану дихальної та серцево-судинної системи.

3. Нормовані коефіцієнти канонічної дискримінантної функції дозволяють визначити співвідно- шення вкладу змінних у результат функціі. 3 найбільшим вкладом в канонічну функцію 1 входять змінні 3, 4 і 7: чим більші значення цих змінних, тим більше значення функції. 3 найбільшим вкладом в канонічну функцію 2 входять змінні 1,8 і 5 : чим більші значення цих змінних, тим більше значення функції. Перша функція на 96,9\% пояснює варіацію результатів, друга - на 3,1\%. Вищевикладене свідчить про можливість класифікації вікових відмінностей дівчат 9-11 класів на основі тестування функціональної, силової і координаційної підготовленості.

4. Структурні коефіцієнти канонічної дискримінантної функції свідчать, що вона найбільш суттєво зв'язана з № 9, 7 і 6 змінними: отже суттєва різниця між дівчатами 9-11 класів спостерігається у пробах Серкіна, Штанге, швидкісній силі.

5. Для підсумкового педагогічного контролю рухової і функціональної підготовленості дівчат 9-11 класів може бути використана перша дискримінантна функція з акцентом на найбільш інформативні змінні.

Перспективою подальших розвідок є розробка методологічних підходів до педагогічного контролю рухової підготовленості дітей і підлітків.

\section{Література}

1. Арефьев В.Г., Моделирование дифференцированной физической подготовленности школьников // Педагогика, психология и медико-биологические проблемы физического воспитания и спорта. 2014. — № 1. — С.3-8. doi:10.6084/m9.figshare.894383

2. Ашмарин Б. А. Методика педагогических исследований в физическом воспитании / Б. А. Ашмарин. - Л. : ЛГПИ им. Герцена, 1973. - 142 с.

3. Бальсевич В.К. Онтокинезиология человека / Бальсевич В.К. - М.: Теория и практика физической культуры, 2000. - 275 с.

4. Дубровский В. И. Спортивная медицина:Учебник для студентов вузов, обучающихся по педагическим спеціальностям. - 3-е изд. - М. : Гуманитар. изд. центр ВЛАДОС, $2005-528$ с.

5. Ермаков С. Модели биомеханических систем в организации эффективного действия спортсмена./ Ермаков С.// Педагогіка, психологія та медико-біологічні проблеми фізичного виховання і спорту. 2001. — № 17. - С. 40-47.

6. Ермаков С. С. Модели рабочих поз спортсмена как фактор эффективности выполнения двигательных действий / Ермаков С. С. //Физическое воспитание студентов творческих специальностей. — 2001. — №4. - С. 16-22.

7. Єрмаков С. С. Біомеханічні моделі ударних рухів у спортивних іграх у контексті вдосконалення технічної підготовки спортсменів. / Єрмаков С. С. // Теорія та методика фізичного виховання. - 2010. - №4. - C. 11-18.

\section{References}

1. Arefev V.G. (2014). Modelirovanie differentsirovannoy fizicheskoy podgotovlennosti shkolnikov. Pedagogika, psihologiya ta mediko-biologichni problemi fizichnogo vihovannya $i$ sportu, (1), 3-8. doi:10.6084/ m9.figshare.894383

2. Ashmarin B. A. (1973). Metodika pedagogicheskih issledovanij v fizicheskom vospitanii. L. : LGPI im. Gercena, 142.

3. Balsevich V.K. (2000). Ontokineziologiya cheloveka. M.: Teoriya i praktika fizicheskoy kulturyi, 275 c.

4. Dubrovskij V. I. (2005). Sportivnaja medicina: Uchebnik dlja studentov vuzov, obuchajushhihsja po pedagicheskim special'nostjam. 3-e izd. M. : Gumanitar. izd. centr VLADOS, 528.

5. Iermakov S. (2001). Modeli biomehanicheskih sistem $\mathrm{v}$ organizacii jeffektivnogo dejstvija sportsmena. Pedagogika, psihologiya ta mediko-biologichni problemi fizichnogo vihovannya i sportu, (17), 40-47.

6. Iermakov S. S. (2001). Modeli rabochih poz sportsmena kak faktor jeffektivnosti vypolnenija dvigatel'nyh dejstvij. Fizicheskoe vospitanie studentov tvorcheskih special'nostej, (4), 16-22.

7. Iermakov S. S. (2010). Biomekhanichni modeli udarnykh rukhiv u sportyvnykh ihrakh u konteksti vdoskonalennya tekhnichnoyi pidhotovky sport.smeniv. Teoria ta metodika fizicnogo vihovanna [Theory and methods of the physical education], (4), 11-18.

8. Ilin P.E. (2003). Psihomotornaya organizatsiya cheloveka: Uchebnik dlya vuzov. SPb.: Piter, 384. 
8. Ильин П.Е. Психомоторная организация человека: Учебник для вузов. - СПб.: Питер, 2003. - 384 с.

9. Іващенко О. В. Вікова динаміка функціональної, координаційної й силової підготовленості дівчат 8-9 класів / О. В. Іващенко, Т. В. Карпунець, Ю. В. Крінін // Теорія та методика фізичного виховання. - 2014. — № 1. - C. 34-42. — DOI:http://dx.doi.org/10.17309/ tmfv.2014.1.1043

10. Иващенко О.В. Нормативные показатели тренировочных нагрузок на начальном этапе подготовки юных гимнасток 6-8 лет: Автореф. дис. ... канд. пед. наук. 13.00.04 / Иващенко О.В. - М.: НИИ физиологии детей и подростков, 1988. - 17 с.

11. Іващенко О.В. Особливості розвитку рухових здібностей у дівчат середніх класів / Іващенко О.В., Пелепенко О.В.// Теорія та методика фізичного виховання. - 2011. — № 10. - C. 3-9. DOI: http://dx.doi. org/10.17309/tmfv.2011.10.743

12. Іващенко О. В. Особливості функціональної, координаційної і силової підготовленості хлопців 8-9 класів / О. В. Іващенко, О. М. Худолій // Теорія та методика фізичного виховання. - 2014. № 1. - C. 15-23. - DOI:http://dx.doi.org/10.17309/ tmfv.2014.1.1041

13. Іващенко О. В. Особливості функціональної, координаційної й силової підготовленості юнаків 9-11 класів / О. В. Іващенко // Теорія та методика фізичного виховання. - 2014. - № 1. - С. 24-33. DOI:http://dx.doi.org/10.17309/tmfv.2014.1.1042

14. Іващенко О. В. Порівняльна характеристика координаційної і силової підготовленості учнів середніх класів / О. В. Іващенко, Г. П. Шепеленко // Теорія та методика фізичного виховання. - 2014. — № 2. - C. 22-30. — DOI:http://dx.doi.org/10.17309/ tmfv.2014.2.1096

15. Іващенко О. В. Порівняльна характеристика функціональної, координаційної і силової підготовленості хлопців 8-9 класів / О. В. Іващенко, С. А. Пашкевич, Ю. В. Крінін // Теорія та методика фізичного виховання. - 2014. - № 2. - С. 31-39. DOI:http://dx.doi.org/10.17309/tmfv.2014.2.1099

16. Козіна Ж. Л. Факторна структура загальної фізичної підготовленості дівчаток $11-15$ років / Ж. Л. Козіна, Н. Попова // Теорія та методика фізичного виховання. - 2013. - № 4. - C. 48-52. — DOI:http:// dx.doi.org/10.17309/tmfv.2013.4.1036

17. Кравчук Т. М. Використання засобів боді-балету в процесі фізичного виховання старшокласниць / Т. М. Кравчук, О. С. Курочка // Теорія та методика фізичного виховання. — 2013. - № 4. - С. 40-47. DOI:http://dx.doi.org/10.17309/tmfv.2013.4.1035

18. Круцевич Т. Ю., Безверхня Г. В. Рекреація у фізичній культурі різних груп населення: Навч. посібник / Круцевич Т. Ю., Безверхня Г. В. - К.: Олімп. л-ра, 2010. - 248 c.

19. Круцевич Т.Ю. Научные исследования в массовой физической культуре. - К.: Здоров’я, 1985. - С. $30-35$.

20. Лях В. І. Двигательные способности школьников: Основы теории и методики развития. - М.: Терра - Спорт, 2000. - 192 с.
9. Ivashchenko O.V., \& Karpunets T. V., \& Krinin Yu. V. (2014). Vikova dinamika funktsionalnoyi, koordinatsiynoyi y silovoyi pidgotovlenosti divchat 8-9 klasiv. Teoria ta metodika fizicnogo vihovanna [Theory and methods of the physical education], (1), 34-42. DOI:http://dx.doi.org/10.17309/tmfv.2014.1.1043

10. Ivashhenko O.V. (1988). Normativnye pokazateli trenirovochnyh nagruzok na nachal'nom jetape podgotovki junyh gimnastok 6-8 let: Avtoref. dis. ... kand. ped. nauk. 13.00.04. M.: NII fiziologii detej i podrostkov, 17.

11. Ivashchenko O.V., \& Pelepenko O.V. (2011). Osoblyvosti rozvytku rukhovykh zdibnostey u divchat serednikh klasiv. Teoria ta metodika fizicnogo vihovanna [Theory and methods of the physical education], (10) 3-9. DOI: http://dx.doi.org/10.17309/tmfv.2011.10.743

12. Ivashchenko O.V., \& Khudolii O.M. (2014). Osoblivosti funktsionalnoyi, koordinatsiynoyi i silovoyi pidgotovlenosti hloptsiv 8-9 klasiv. Teoria ta metodika fizicnogo vihovanna [Theory and methods of the physical education], (1), 15-23. - DOI:http://dx.doi. org/10.17309/tmfv.2014.1.1041

13. Ivashchenko O.V. (2014). Osoblivosti funktsionalnoyi, koordinatsiynoyi y silovoyi pidgotovlenosti yunakiv 9-11 klasiv. Teoria ta metodika fizicnogo vihovanna [Theory and methods of the physical education], (1), 24-33. - DOI:http://dx.doi.org/10.17309/ tmfv.2014.1.1042

14. Ivashchenko O.V., \& Shepelenko G. P. (2014). Porivnyalna harakteristika koordinatsIynoyi i silovoyi pidgotovlenosti uchniv serednih klasiv. Teoria ta metodika fizicnogo vihovanna [Theory and methods of the physical education], (2), 22-30. DOI:http://dx.doi. org/10.17309/tmfv.2014.2.1096

15. Ivashchenko O.V., Pashkevich S. A., \& Krinin Yu. V. (2014). Porivnyalna harakteristika funktsionalnoyi, koordinatsiynoyi i silovoyi pidgotovlenosti hloptsiv 8-9 klasiv. Teoria ta metodika fizicnogo vihovanna [Theory and methods of the physical education], (2), 3139. DOI:http://dx.doi.org/10.17309/tmfv.2014.2.1099

16. Kozina Zh.L., Popova N. (2013). Faktorna struktura zagalnoyi fizichnoyi pidgotovlenosti divchatok 11-15 rokiv. Teoria ta metodika fizicnogo vihovanna [Theory and methods of the physical education], (4), 48-52. DOI: http://dx.doi.org/10.17309/tmfv.2013.4.1036

17. Kravchuk T. M., \& Kurochka O. S. (2013). Vikoristannya zasobIv bodI-baletu v protsesI fIzichnogo vihovannya starshoklasnits. Teoria ta metodika fizicnogo vihovanna [Theory and methods of the physical education], (4), 4047. DOI:http://dx.doi.org/10.17309/tmfv.2013.4.1035

18. Krutsevich T. Yu. \& Bezverhnya G. V. (2010).Rekreatsiya u fizichniy kulturi riznih grup naselennya: Navch. posibnik. K.: Olimp. 1-ra, 248.

19. Krucevich T.Ju. (1985). Nauchnye issledovanija v massovoj fizicheskoj kul'ture. K.: Zdorov'ja, 30-35.

20. Ljah V. I. (2000). Dvigatel'nye sposobnosti shkol'nikov: Osnovy teorii i metodiki razvitija. M.: Terra - Sport, 192.

21. Marchenko S. I. (2009). Modelyuvannya rozvytku shvydkosti u shkolyariv 2-4 klasiv zasobamy rukhlyvykh ihor. Teoria ta metodika fizicnogo vihovanna [Theory and methods of the physical education], (10), 
21. Марченко С. І. Моделювання розвитку швидкості у школярів 2-4 класів засобами рухливих ігор / С. I. Марченко // Теорія та методика фізичного виховання. - 2009. - № 10. - С. 10-14. - Режим доступу: http://www.tmfv.com.ua/journal/article/view/567.

22. Марченко С. I. Характеристика впливу ігрових засобів на динаміку розвитку витривалості в учнів молодшого шкільного віку / С. І. Марченко // Теорія та методика фізичного виховання. - 2008. - № 10. - C. 38-49. - Режим доступу: http://www.tmfv.com. ua/journal/article/view/465

23. Носко М.О., Теоретико-методичні аспекти зміцнення фізичного здоров'я учнівської та студентської молоді / Носко М.О., Єрмаков С.С., Гаркуша С.В.// Вісник Чернігівського національного педагогічного університету. Серія : Педагогічні науки. Фізичне виховання та спорт / Черніг. нац. пед. ун-т ім. Т. Г. Шевченка. - Чернігів: Вид-во ЧДПУ, 2010. - Вип. 76. - C. 243-247.

24. Сергієнко Л. П. Тестування рухових здібностей школярів. - К.: Олімпійська література, $2001-439$ с.

25. Соляник I. Є. Особливості розвитку рухових здібностей у хлопців 6-7 класів / I. Є. Соляник // Теорія та методика фізичного виховання. - 2013. — № 3. - C. 22-31. DOI: http://dx.doi.org/10.17309/ tmfv.2013.3.1022

26. Тітаренко А. А. Особливості розвитку рухових здібностей у дівчаток молодшого шкільного віку // Теорія та методика фізичного виховання. - Харків: ОВС, 2010. - № 9. - С. 3-13. Режим доступу: http://www.tmfv.com.ua/journal/article/view/652

27. Тітаренко А. А. Особливості методики розвитку сили у хлопчиків молодшого шкільного віку / Tiтаренко А. А., Худолій О. М. // Теорія та методика фізичного виховання. - 2011. - № 1. - С. 3-18, 35-40. Отримано з http://www.tmfv.com.ua/journal/ article/view/682

28. Ткаченко С.Н., Применение здоровьесберегающих технологий на уроках футбола с девочками среднего школьного возраста // Педагогика, психология и медико-биологические проблемы физического воспитания и спорта. - 2014. - № 11. - С. 61-65. doi:10.15561/18189172.2014.1111

29. Филин В.П. Методы исследования в спорте: Учебное пособие / В.П. Филин, А.С. Ровний. - Харьков: Основа, 1992. - С. 63-68.

30. Худолій, О.М. Моделювання розвитку швидкісносилових здібностей у школярів 2-4 класів засобами рухливих ігор / Худолій, О.М., Марченко, С.I. // Педагогіка, психологія та медико-біологічні проблеми фізичного виховання в спорту. - 2007. - № 8. - С. 139-142.

31. Худолій О. М. Інформаційне забезпечення процесу навчання і розвитку рухових здібностей дітей і підлітків (на прикладі спортивної гімнастики) / Худолій О. М., Іващенко О. В. // Теорія та методика фізичного виховання. - Харків: ОВС, 2013. № 4. - C. 3-18. DOI: http://dx.doi.org/10.17309/ tmfv.2013.4.1031

32. Худолій О. М., Закономірності процесу навчання юних гімнастів / Худолій О. М., Єрмаков С. С. // Тео-
10-14. - Режим доступу: http://www.tmfv.com.ua/ journal/article/view/567.

22. Marchenko S. I. (2008). Kharakterystyka vplyvu ihrovykh zasobiv na dynamiku rozvytku vytryvalosti v uchniv molodshoho shkil'noho viku. Teoria ta metodika fizicnogo vihovanna [Theory and methods of the physical education], (10), 38-49. - Режим доступу: http://www.tmfv.com.ua/journal/article/view/465

23. Nosko M.O., Iermakov S.S., \& Garkusha S.V. (2010). Theoretical and methodological aspects of strengthening physical health of pupils and students. Visnik Chernigivs'kogo nacional'nogo pedagogichnogo universitetu, (76), 243-247.

24. Serhiyenko L. P. (2001). Testuvannya rukhovykh zdibnostey shkolyariv. K.: Olimpiys'ka literatura, 439.

25. Solyanyk I. Ye. (2013). Osoblyvosti rozvytku rukhovykh zdibnostey u khloptsiv 6-7 klasiv. Teoria ta metodika fizicnogo vihovanna [Theory and methods of the physical education], (3), 22-31. DOI: http://dx.doi. org/10.17309/tmfv.2013.3.1022

26. TItarenko A. A. (2010). Osoblivosti rozvitku ruhovih zdibnostey u divchatok molodshogo shkilnogo viku. Teoria ta metodika fizicnogo vihovanna [Theory and methods of the physical education], (9), 3-13. Режим доступу: http://www.tmfv.com.ua/journal/article/ view/652

27. Titarenko A. A., \& Khudolii O. M. (2011). Osoblyvosti metodyky rozvytku syly u khlopchykiv molodshoho shkil'noho viku. Teoria ta metodika fizicnogo vihovanna [Theory and methods of the physical education], (1), 3-18, 35-40. Отримано 3 http://www.tmfv.com.ua/ journal/article/view/682

28. Tkachenko S.N. (2014). Primenenie zdorovesberegayuschih tehnologiy na urokah futbola s devochkami srednego shkolnogo vozrasta. Pedagogika, psihologiya ta mediko-biologichni problemi fizichnogo vihovannya i sportu,, (11), 61-65. doi:10.15561/18189172.2014.1111

29. Filin V.P., \& Rovnij A.S. (1992). Metody issledovanija v sporte: Uchebnoe posobie. Har'kov: Osnova, 63-68.

30. Khudolii, O., \& Marchenko, S. (2007). Modelyuvannya rozvytku shvydkisno-sylovykh zdibnostey u shkolyariv 2-4 klasiv zasobamy rukhlyvykh ihor. Pedagogika, psihologiya ta mediko-biologichni problemi fizichnogo vihovannya i sportu, (8), 139-142.

31. Khudolii O. M., \& Ivashchenco O. V. (2013). Informatsiyne zabezpechennya protsesu navchannya i rozvitku ruhovih zdibnostey ditey i pidlitkiv (na prikladi sportivnoyi gimnastiki). Teoria ta metodika fizicnogo vihovanna [Theory and methods of the physical education], (4), 3-18. DOI: http://dx.doi. org/10.17309/tmfv.2013.4.1031

32. Khudolii O.M., \& IermakovS.S. (2011).Zakonomirnosti protsesu navchannya yunih gimnastiv. Teoria ta metodika fizicnogo vihovanna [Theory and methods of the physical education], (5), 3-18, 35-41. DOI: http:// dx.doi.org/10.17309/tmfv.2011.5.707

33. Khudolii O. M., Ivashchenco O. V., \& Pimenov O. O. (2012). Osoblivosti silovoyi pidgotovlenosti shkolyariv starshih klasiv. Teoria ta metodika fizicnogo vihovanna [Theory and methods of the physical education], 
рія та методика фізичного виховання. - 2011. - № 5. - C. 3-18,35-41. DOI: http://dx.doi.org/10.17309/ tmfv.2011.5.707

33. Худолій О. М., Особливості силової підготовленості школярів старших класів / Худолій О. М., Іващенко О. В., Піменов О. О. // Теорія та методика фізичного виховання. - 2012. - №9. - C. 37-41. DOI: http://dx.doi.org/10.17309/tmfv.2012.9.822

34. Худолій О. М. Особливості функціональної, координаційної і силової підготовленості дівчат 7-8 класів / О. М. Худолій, О. В. Іващенко // Теорія та методика фізичного виховання. - 2014. № 2. - C. 15-21. - DOI:http://dx.doi.org/10.17309/ tmfv.2014.2.1095

35. Худолій О.М. Моделювання процесу навчання та розвитку рухових здібностей у дітей і підлітків: Монографія / Худолій О.М., Іващенко О.В. - Харків: ОВС, 2014. - $320 \mathrm{c}$.

36. Худолій О. М. Методика планування навчальної роботи з гімнастики в школі / О. М. Худолій // Теорія та методика фізичного виховання. - 2008. № 9. - C. 19-35. - DOI:http://dx.doi.org/10.17309/ tmfv.2008.9.454

37. Шиян Б. М., Папуша В. Г. Методика викладання спортивно-педагогічних дисциплін у вищих навчальних закладах фізичного виховання і спорту: Навчальний посібник. - Харків: «ОВС», 2005. - 208 с.

38. Adashevskiy, V. M., Iermakov, S. S. (2013). Physical mathematical modelling of difficult elements of acrobatic rockand-roll. / Adashevskiy, V. M., \& Iermakov, S. S. // Physical Education of Students. - 2013. - № 3. - P. 3-10.

39. Dorita DU TOIT, Anita E. PIENAAR \& Leani TRUTER (2011) Relationship between physical fitness and academic performance in south african children // SAJR SPER, 33(3), 2011. - Pp. 23-35.

40. Geoffrey D. Broadhead And Gabie E. Church (1982) Discriminant analysis of gross and fine motor proficiency data. Perceptual and Motor Skills: Volume 55, Issue , pp. 547-552. doi: http://dx.doi.org/10.2466/ pms.1982.55.2.547

41. Gert-Jan de Bruijn and Benjamin Gardner (2011) Active Commuting and Habit Strength: An Interactive and Discriminant Analyses Approach. American Journal of Health Promotion: January/February 2011, Vol. 25, No. 3, pp. e27-e36. doi: http://dx.doi.org/10.4278/ ajhp.090521-QUAN-170

42. Lulzim, I., (2013) Discriminant analysis of morphologic and motor parameters of athlete and non athlete girl pupils of primary school on age 14 to 15 years. RIK(2012) Vol.40, No.2, pp 185-190. http://fsprm.mk/ wp-content/uploads/2013/08/Pages-from-SpisanieRIK-br.-2-2012-9.pdf

43. Milić, M., Milavić, B., \& Grgantov, Z. (2011). Relations between sport involvement, selfesteem, sport motivation and types of computer usage in adolescents. In S. Simović (Ed.), Proceedings of 3rd International Scientific Congress «Anthropological Aspects of Sport, Physical Education and Recreation». November 2011. Banja Luka: University of Banja Luka, Faculty of Physical Education and Sport (in press)
(9), 37-41. DOI: http://dx.doi.org/10.17309/ tmfv.2012.9.822.

34. Khudolii O. M., \& Ivashchenco O. V. (2014). Osoblivosti funktsionalnoyi, koordinatsiynoyi i silovoyi pidgotovlenosti divchat 7-8 klasiv. Teoria ta metodika fizicnogo vihovanna [Theory and methods of the physical education], (2), 15-21. - DOI:http://dx.doi. org/10.17309/tmfv.2014.2.1095

35. Khudolii O. M., \& Ivashchenco O. V. (2014). Modelyuvannya protsesu navchannya ta rozvitku ruhovih zdibnostey u ditey i pidlitkiv: Monografiya. Harkiv: OVS, 320.

36. Khudolii O. M. (2008). Metodyka planuvannya navchal'noyi roboty $\mathrm{z}$ himnastyky $\mathrm{v}$ shkoli. Teoria ta metodika fizicnogo vihovanna [Theory and methods of the physical education], (9), 19-35. - DOI:http:// dx.doi.org/10.17309/tmfv.2008.9.454

37. Shiyan B. M. \& Papusha V. G. (2005). Metodika vikladannya sportivno-pedagogichnih distsiplin $u$ vischih navchalnih zakladah fizichnogo vihovannya i sportu: Navchalniy posibnik. Harkiv: «OVS», 208.

38. Adashevskiy, V. M., Iermakov, S. S. (2013). Physical mathematical modelling of difficult elements of acrobatic rockand-roll. / Adashevskiy, V. M., \& Iermakov, S. S. // Physical Education of Students. — 2013. - № 3. - P. 3-10.

39. Dorita DU TOIT, Anita E. PIENAAR \& Leani TRUTER (2011) Relationship between physical fitness and academic performance in south african children // SAJR SPER, 33(3), 2011. - Pp. 23-35.

40. Geoffrey D. Broadhead And Gabie E. Church (1982) Discriminant analysis of gross and fine motor proficiency data. Perceptual and Motor Skills: Volume 55, Issue , pp. 547-552. doi: http://dx.doi.org/10.2466/ pms.1982.55.2.547

41. Gert-Jan de Bruijn and Benjamin Gardner (2011) Active Commuting and Habit Strength: An Interactive and Discriminant Analyses Approach. American Journal of Health Promotion: January/February 2011, Vol. 25, No. 3, pp. e27-e36. doi: http://dx.doi.org/10.4278/ ajhp.090521-QUAN-170

42. Lulzim, I., (2013) Discriminant analysis of morphologic and motor parameters of athlete and non athlete girl pupils of primary school on age 14 to 15 years. RIK(2012) Vol.40, No.2, pp 185-190. http://fsprm.mk/ wp-content/uploads/2013/08/Pages-from-SpisanieRIK-br.-2-2012-9.pdf

43. Milić, M., Milavić, B., \& Grgantov, Z. (2011). Relations between sport involvement, selfesteem, sport motivation and types of computer usage in adolescents. In S. Simović (Ed.), Proceedings of 3rd International Scientific Congress "Anthropological Aspects of Sport, Physical Education and Recreation». November 2011. Banja Luka: University of Banja Luka, Faculty of Physical Education and Sport (in press) 


\title{
ДИСКРИМИНАНТНЫЙ АНАЛИЗ В ОЦЕНКЕ ФУНКЦИОНАЛЬНОЙ И ДВИГАТЕЛЬНОЙ ПОДГОТОВЛЕННОСТИ ДЕВУШЕК СТАРШИХ КЛАССОВ
}

\author{
Худолей О.Н., Иващенко А.В. \\ Харьковский национальный педагогический университет имени Г. С. Сковороды \\ Реферат. Статья: 7 с., 9 табл., рис. 1, 43 источники.
}

Цель исследования - определить методологические подходы к педагогическому контролю двигательной и функциональной подготовленности девушек старших классов.

Методы исследования. Для решения поставленных задач были применены следующие методы исследования: анализ научной литературы, педагогическое тестирование и методы математической статистики.

Для оценки функциональной и двигательной подготовленности девушек 9-11 классов регистрировались результаты проб Штанге, Генчи, Серкина и двигательных тестов. В исследовании приняли участие девушки 9 класса -24 человек, 10 класса - 21 человек, 11 класса -26 человек.

Результаты. Нормированные коэффициенты канонической дискриминантной функции позволяют определить соотношение вклада переменных в результат функции. С наибольшим вкладом в каноническую функцию 1 входят переменные 3, 4 и 7: чем больше значения этих переменных, тем большее значение функции. С наибольшим вкладом в каноническую функцию 2 входят переменные 1 ,
8 и 5: чем больше значения этих переменных, тем большее значение функции. Первая функция на 96,9\% объясняет вариацию результатов, вторая на $3,1 \%$. Вышеизложенное свидетельствует о возможности классификации возрастных различий девушек 9-11 классов на основе тестирования функциональной, силовой и координационной подготовленности.

Структурные коэффициенты канонической дискриминантной функции свидетельствуют, что она наиболее существенно связана с № 9, 7 и 6 переменными: значит существенная разница между девушками 9-11 классов наблюдается в пробах Серкина, Штанге, скоростной силе.

Выводы. Для итогового педагогического контроля двигательной и функциональной подготовленности девушек 9-11 классов может быть использована первая дискриминантная функция с акцентом на наиболее информативные переменные.

Ключевые слова. Дискриминантная функция; педагогический контроль; классификация; моделирование; двигательная подготовленность; девушки 9-11 классов.

\section{DISCRIMINANT ANALYSIS IN THE ASSESSMENT OF FUNCTIONAL AND MOTOR PREPAREDNESS OF HIGH SCHOOL GIRLS}

\author{
Khudolii O. M., Ivashchenko O.V. \\ G.S. Skovoroda Kharkiv National Pedagogical University \\ Report. Article: 6 p., 5 tables., 37 sources
}

The aim - to define methodological approaches to teaching motor control and functional readiness of high school girls.

Research methods. To achieve the objectives adopted the following methods: analysis of scientific literature, teaching and testing methods of mathematical statistics.

To evaluate the functional and physical fitness of girls grades 9-11 trial results registered post, Ghencea, Serkina and motor tests. In the study involved girls in grade $9-24$ persons, 10 class -21 people, 11 class 26 people.
Results. Standardized canonical discriminant function coefficients can determine the value contribution of variables in the function result. With the largest contribution to the canonical function of one variable are 3, 4 and 7: the higher the value of these variables, the more important functions. With the largest contribution to the canonical function of two variables are 1, 8 and 5: The higher the value of these variables, the more important functions. The first function is to explain $96.9 \%$ variance of results, the second - by $3.1 \%$. The foregoing demonstrates the possibility of classifying differences in age girls grades 
9-11 based functional testing, power and coordination training.

Structural canonical discriminant function coefficients indicate that it is most significantly associated with the number 9, 7 and 6 variables: thus a significant difference between girls grades 9-11 there in the samples Serkina, weights, speed force.
Conclusions. For the final pedagogical control motor and functional training girls grades $9-11$ can be used first discriminant function with an emphasis on the most informative variables.

Keywords. Discriminant function; pedagogical control; classification; modeling; motor preparedness; girls grades $9-11$.

\section{Інформація про авторів:}

Худолій Олег Миколайович: ORCID 0000-0002-56059939; tmfv@tmfv.com.ua; Харківський національний педагогічний університет імені Г.С. Сковороди, вул. Артема, 29, м. Харків, 61002, Україна.

Іващенко Ольга Віталіївна: ORCID 0000-0002-27085636; tmfv@tmfv.com.ua; Харківський національний педагогічний університет імені Г.С. Сковороди, вул. Артема, 29, м. Харків, 61002, Україна.
Цитуйте статтю як: Худолій О.М. Дискримінантний аналіз в оцінці функціональної і рухової підготовленості дівчат старших класів / Худолій О.М., Іващенко О. В. // Теорія та методика фізичного виховання. - 2014. — № 4. - C. 12-22. DOI: http://dx.doi.org/10.17309/ tmfv.2014.4.1113

Стаття надійшла до редакції: 05.11.2014 р. Прийнята: 15.12.2014. Надрукована: 25.12.2014 